\title{
GLOBALIZATION - A CHALLENGE FOR MODERN EDUCATION
}

\section{Poluiaktova O. V.}

\section{INTRODUCTION}

In the last quarter of the XX -the early XXI century, there has been economic, social and political, cultural development under the growing impact of globalisation. Its economic component is primarily related to sources, factors, forms of economic progress. Globalisation of the world economy has led to the fact that fierce global competition requires constant innovation, new ideas, and high-quality products. The world economy enters a new phase based on information technologies that do not demand large investments in the development of traditional infrastructure. The focus is shifted on connection and communication, and as a consequence the role of intellectual capital, not of tangible, is raised. It is formed mainly by knowledge and information.

Modern development of economics requires fast social-political and technological changes based on scholarly knowledge. Today, knowledge is the main source for achieving high social and economic results. First of all, knowledge is thoughts and experience, approaches and ideas regarding how production should be organised, what product should be like in order to meet all increasing human demands etc. The knowledge is manifested in the skills and abilities of people and is consolidated in the form of organizational culture, brands, patents, licenses, organizational structures, methods of interaction between enterprises and institutions.

Is the education sector able to recognise its extent of liability in searching for methods of training of competitive experts? How, in what way should education develop in the future, what are its strategic priorities and values?

In the context of dynamic changes of external and internal environment, the architecture of higher education is complicated and needs extreme, recombination and modification innovation aimed at obtaining or keeping leader position by higher education institution, reaching competitiveness at the market of educational services, management efficiency, meeting demands of receivers of educational 
services ${ }^{1}$. Education should get ahead of life. This is a fundamental truth that has been confirmed for a long time.

The era of technological revolution is primarily about the development of the mental functions of the employee, increasing of his or her relative share of creative intellectual origin, the ability to perceive information, process it, acquire new knowledge improving production on this basis, manage complex technological cycles.

In all developed countries, the factors of economic growth have changed and the role of research activities in production has sharply risen, and scientific areas have taken the centerpiece in economics. The main value of modern society is highly qualified experts who effectively use their intellectual potential to generate new ideas. The fundamental changes in the technical and technological basis of production require adequate changes in the professional and qualification structure of the workforce. New spheres of work have emerged, and vocational training of employees has been a decisive factor in economic growth. Malfunctions due to lack of skills can lead to excessive charges or accidents. All of these things objectively led to an increased focus on education and highly educated people as the main force not only of production but of the entire social life.

A source of acceleration of economic development that can provide immediate output in case of competent use is the growth of intellectual capacity. Challenges of countries are to change the model of socioeconomic development from monetary approach and extensive exploitation of human and natural resources to effective use of science and innovation. This is especially important taking into account the intellectual potential, global trends and processes of the intellectualisation of work and socio-economic life in general, the nature and speed of which form a new look to the world model and place of individual states in it.

\section{Education as a factor of economic growth in the context of globalization}

There are two main approaches to the periodisation of economic globalization. According to the first approach, globalization dated even before the Age of Discovery. The second approach is based on the fact

1 Ямков В. Ранжування університетів крок до відкритості та прозорості вищої освіти. Освіта Украӥни. 2007. № 42. 
that globalization is peculiar exclusively to the economic growth of the late XXth century. At this point in history, globalization is a driver of both national and international development and evolves into the dominant trend in world economic processes ${ }^{2}$.

The process of globalization is in progress under the influence of a set of factors. Among them are scientific and technological progress, a revolution in information technology; development of international infrastructure, new generations of transport and communications; extension of the international division of labour, further development of the internationalization of production; descent of the role of traditions, social ties and customs, internationalization of education, cultural space etc.

At the same time, globalization has a contradictory impact on both individual states and the world economy as a whole. On the one hand, it opens up previously unprecedented economic growth opportunities driven by accelerating the process of dissemination of advanced technologies, development of creativity and innovations; improving the mechanism for allocating resources, improving the efficiency of their use based on the development of global competition; enhancing the quality of life, improving the welfare of families, expanding multi-options and access to new ideas and knowledge; strengthening international coordination, reducing the threat of international conflicts, local wars; the spread of ideas of humanism, democracy, protection of civil rights and fundamental human freedoms.

Economic globalization also generates unprecedented threats and risks as a result of intensification of inequality of socio-economic development of countries on the global scale; amplification of imbalances in the world economy, increase of the gap between the commodity and financial markets, the threats of global crises; growing conflicts of different nature and scale, creation of a global network of criminal business, international terrorism; loss of national identity, extension of uniform standards to national cultures; exacerbation of global problems ${ }^{3}$.

In general, globalization is a complex, multifaceted process that covers all aspects of social development and is realised in the growing

2 Філіпенко А.С. Глобальні форми економічного розвитку: історія і сучасність. К.: Знання, 2007.670 с.

${ }^{3}$ Мочерний С. В. Основи економічних знань. Київ, 1996. 405 с. 
interdependence of the countries across the world as a result of the formation of a single world economic organism.

Today, analysis of the global trends that emerged in the XX century is of a special topicality and significance; they can run and run in the current century, thus challenging human civilization. The challenge directly concerns the education sector aimed at adjusting its priorities and values, taking into account not only currently important but also perspective, long-term demands of both human being and society ${ }^{4}$.

The new paradigm of economic development based on knowledge and information technologies erases the national boundaries of competition, objectively promotes the intellectual and educational potential of the country as a key resource for economic growth. Therefore, in the present context, the only educational system that takes into account the processes of globalization can provide a successful career.

Globalization is perhaps the greatest fundamental challenge to education. The world we live in is significantly changing, becoming more volatile and unpredictable. VUCA world is a frozen term, people live and work inside uncertainty (VUCA is an acronym of the English words: volatility, uncertainty, complexity i ambiguity) ${ }^{5}$. What an expert should be not only over the next while but also in modern society to be competitive, successful, in demand in the labour market - these issues are now very popular among the most burning issues.

Adam Smith wrote that "increase in productivity of useful work depends first and foremost on improving the skill and ability of the worker and then on improving the machines and tools he used"

D. Ricardo explained countries' lag in economic development, among other reasons, by "lack of education in all population strata" .

H. de Saint-Simon expressed the important statement that in the future, technical and scientific knowledge would become especially significant, and "the steady aim of the public organization would be better application of the knowledge gained by the sciences, arts and crafts,

${ }^{4}$ Гершунский Б. С. Философия образования для XXI века (В поисках практикоориентированных образовательных концепций). Москва, 1997. 697 с.

5 Менеджмент підприємницької діяльності: навч. посіб. для професійної підготовки військовослужбовців ЗС України звільнених у запас. Проект «УкраїнаНорвегія». Вип. 6, Одеса: Видавничий дім «Гельветика». 2018. 240 с.

${ }^{6}$ Смит А. Исследование о природе и причинах богатства народов. Москва: Соцэкгиз, 1956. $490 \mathrm{c}$.

${ }^{7}$ Рикардо Д. Сочинения. Москва, 1995. Т. 1. 365 с. 
amplification of the knowledge, its improvement and more accumulation". J. Mill as well as his predecessor was a follower of the development of industrial society. In his opinion, deficiencies can be eliminated only when the degree of freedom of all members of society increases that is considered to be the most important condition for social progress ${ }^{8}$.

Human activity is increasingly acquiring spiritual dimension. Physical work stands down mental one. It is not the "salariat" (hired workers) but the "cognitariat" - scientists, engineers, experts are quite independent due to their intelligence level - they become leaders of society and creators of technological innovations ${ }^{9}$.

In 1962 F. Machlup introduced the term "intellectual worker" for scientific use where he emphasized previously unknown characteristics of a new type of employee: his/her orientation and handling of information and knowledge; high mobility and drive for an activity that opens the space for self-realization and self-expression, even to the detriment of instant financial benefit. In this context, there are interesting reflections of academician V. Semynozhenko regarding the humanitarian-innovation revolution. "An individual has become not the abstract value but the basis for all kinds of politics and first of all, the main object of investment and the main carrier of economic profits"

Thus, there is a graduation in views regarding the objective processes of development of productive forces, when the role and importance of his/her educational level, qualification, intelligence, competence, scientific knowledge unprecedentedly grow up in the economics of the human person.

Modern society, as never before, needs a creative person focused on innovation, initiatives. Only such a person - the carrier of intellectual potential - is able to develop his/her abilities, talents and endowments; his/her activity can provide a qualitatively new state of society the achievement of which is our strategic goal. Increase of the role of intellectual potential at the present stage is a fitting result of progressive development.

8 Иноземцев В. Л. К теории постэкономической общественной формации. Москва: Таурус, 1995. 302 с.

9 Хорос В. Постиндустриальный мир - надежды и опасения (к постановке проблемы). Москва: МЭ и МО. 1998. № 12.

10 Злупко С. М., Радецький Й. І. Людський потенціал, зайнятість і соціальний захист населення в Україні: Навчальний посібник. Львів: Видавничий центр ЛНУ імені Івана Франка, 2001. 192 с. 
There are great expectations from the youth, its energy and inquiring mind, interest in everything new. In this regard, the responsibility and role of education are increasing which greatly influences the choice of each of their future activities and the formation of the intellectual potential of society. Education and professional training is a multifunctional system with a complex structure. The impact of the system on the life of society is quite wide: in the preschools establishments and general school, the process of formation of a person, individual and social consciousness of the person begins, which also continues in the system of professional training. Nowadays, the role of the education system as an institute of spiritual education of a person, enrichment of its human capital assets, improvement of his/her qualities as a subject of industrial relations is increasing. The above activity of educational institutions acting as a kind of realization of the demand of the state and citizens for educational services needs special support of the state.

The system of education and professional training as an institute of spiritual production, professional and intellectual development of a person, development of his/her creative potential should form such a set of knowledge and skills of the society which could ensure their expedient activity in the system of social division of labour.

Today, any kind of education (general, professional) should provide not only the body of knowledge, not only train experts for a certain type of activity but also contribute to their need to beef up the previously acquired knowledge and skills, broaden their outlook, enhance culture, develop abilities, improve their profession, acquire a new profession. At the moment, one of the main tasks is to determine the degree of training of experts of different areas of expertise in advance. Besides, at the modern stage of development, it is important to organize a qualified and effective form of continuous training and mainly independent training of all employees.

"The future does not belong to those who provide cheap work or have ordinary capital - they will be replaced by automation. Those who are ready to implement innovations and create new products, services and business models will be into luck", Erik Brynjolfsson, Andrew McAfee and Michael Spence believe ${ }^{11}$.

${ }^{11}$ Brynjolfsson E., McAfee A., Spence M. New World Order. Labor, Capital, and Ideas in the Power Law Economy. Foreign Affairs. 2014. № 4, July - Aug. P. 19. 
Sociologist V. I. Ihnatiev gives the following facts: information volume annually increases by $30 \%$, the volume of digital information doubles every 18 months ${ }^{12}$. According to the statement of Executive Chairman of Alphabet's Board, Google parent's company, Eric Schmidt, every two days we create as much information as we did from the date of civilization origin until $2003^{13}$. The number of research increases by $7-9 \%$ a year that equals to doubling scientific productivity every ten years, to put it in crude terms ${ }^{14}$.

University graduates will have to live and work in a new world where the boundaries of national economies become more conditional. In modern conditions, education "product" is an expert - competent, intelligent, skilful, cultural and humane. Thus, competition in the education sector is first and foremost an impetus for deeper cooperation. The need to create a single market for a highly skilled workforce has caused the need for integration in higher education, which is intended to promote the development of the market of high-quality educational services, enhance academic, professional and social mobility of participants of the educational process.

The education sector certainly has the most direct relevance to all events in the world. It is education and only education is able to reverse the catastrophically growing negative tendencies in human life ${ }^{15}$. The challenge of the XXI century addressed the education sector is to awaken the functions of education as the most important sphere of cognition, the formation of correction and transformation of the mentality of the individual and society as a whole.

Today, the educational system has taken a special position in the system of social institutions typical of a post-industrial developing society and forming intelligence society.

The economic dynamics of industrially developed countries linked to the intensification of competition, the rapid change of technology and

12 Игнатьев В. И. Социология информационного общества: учеб. пособник. Новосибирск: Изд-во НГТУ, 2017. 356 с.

${ }^{13}$ Sigler M. G. Eric Schmidt: Every 2 Days We Create As Much Information As We Did Up To 2003. URL:http://techcrunch.com/ 2010/08/04/schmidt-data (дата звернення 25.05.2019)

${ }_{14}$ Фейдл Ч., Бялик М., Триллинг Б. Четырёхмерное образование: компетенции, которые нужны для успеха. URL: http://nios.ru/sites/nios.ru/files/poleznoe/4D_ Education_0.pdf (дата звернення 20.04.2019)

${ }^{15}$ Гершунский Б. С. Философия образования для XXI века (В поисках практикоориентированных образовательных концепций). М., 1997. - 697 с. 
enhancement of economic uncertainty creates a demand for new types of competencies and new forms of human resource training. On the one hand, there is a growing demand for employees with maximum flexibility and a high degree of creativity, who are ready for independent actions and teamwork, able to work in different cultures and with different technological environments. On the other hand, there is a demand for employees who will work with a limited scope of tasks for a particular workplace. From a third perspective, there is a growing need for employees who are ready for thorough lifelong learning that will allow providing ongoing training for staff following a constantly changing range of tasks.

Psychologist Herbert Gerjuoy from the Human Resources Research Organization gives a simple formulation: "New education should teach the individual how to classify and reclassify information, how to evaluate its validity, how to change categories if necessary, how to turn from specific to abstract, and vice versa, how to look at problems under a new perspective, how to engage in self-education. The person who cannot read will be not illiterate in the future, but the one who has not learned to study". According to A.Toffler "people who will live in the superindustrial society need new skills and knowledge in three key spheres: study ability, communication ability and choice ability ${ }^{16}$. The paper notes that the Report of the International Commission on Education for the Twenty-first Century "Education: hidden treasure" also marks and highlights the importance of four basic principles compiling modern education - learning to live, learning to know, learning to do and learning to live with others ${ }^{17}$. According to Aristotle "the human beings naturally follow knowledge", and Cicero wrote "So great is our innate love of learning and of knowledge that no one can doubt that man's nature is strongly attracted to these things even without the lure of any profit" ${ }^{\text {"18. }}$. What do you need to know, to learn, to develop to be competitive in the modern labour market? Majority of education innovators answers that it is important to develop so-called "hard skills" and "soft skills" or

${ }^{16}$ Тоффлер Э. Шок будущего: Пер. с англ. Москва: ООО «Издательство АСТ», $2002.557 \mathrm{c}$.

${ }^{17}$ Образование: сокрытое сокровище (Learning: The Treasure Within). Основные положения Доклада Международной комиссии по образованию для XXI века. MOO ВПП ЮНЕСКО «Информация для всех», 2007 г. URL:www.unesco.org. (дата звернення 12.04.2019)

18 Аристотель. Сочинения в четырех томах. Т. 1. Ред. В. Ф. Асмус. Москва: Мысль, 1976. 550 с. 
"flexible skills". Results of the research undertaken at Harvard University and Stanford Research Institute indicate that the contribution of "hard skills" to the employee's professional success is only $15 \%$, while the soft determine the rest $-85 \%^{19}$. Another research conducted by Stanford Research Institute in cooperation with Carnegie Melon Foundation among CEOs of companies enlisted in "Fortune 500" shows that that long-term and stable success of companies' executives is determined by soft skills by $75 \%$ and by hard skills only by $25 \%$.

The application of soft skills means the ability to use different behaviour models in one situation, fully understand own and others' interests, prioritize in the here and now, decide between alternatives.

Modern society is very interested in the fact that each person makes own individual contribution to the development, renewal of all life spheres. An urgent task of modern education is to reveal the creative possibilities of employees, our personnel, highly educated, professionally trained experts to the full.

The prerequisite for globalization processes is the review and refashioning of the system of international relations in terms of human values, joining efforts and resources of humanity on the basis of an awareness of unity of interests and shared responsibility to future generations.

\section{Mechanism of the functioning of modern markets of educational services}

According to the research of foreign scientists, technologic core involves Japan, USA, Canada, South Korea, and Australia. Organization of innovation activities in the leading countries has the following features: horizontal integration of $\mathrm{R} \& \mathrm{D}$, designing and training, creation of computer networks, joint research, state support for new technologies. The leaders of the advanced countries have discovered that the knowledge, the intellectual resource of the state becomes a decisive factor of development not in the distant future, but today.

At the end of the XXth century, such a branch of the world national economy as the market of educational services was formed. The key

19 Иванов Д. В. Путь к вершине. Факторы успеха. Управление развитием персонала. 2010. URL: https://grebennikon.ru/ author-3753.html (дата звернення 20.04.2019) 
parameters of the market are determined by such indicators as sales volume accounting to tens of billions of US dollars, as well as the international flow of migration, which has academic nature, totalling several million people a year. In 2002 the international market of educational services accounted for almost 3\% of the global services market. In 2013 US revenues driven by the education of international students were nearly 10.29 billion dollars. This figure is higher than the state's funding for higher education in all Latin American countries.

The global education services market increases the number of virtual universities, which accounted for approximately 1180 units in 2015. It is envisaged that as early as 2020, the number of students at such kind of universities may be larger than the number of full-time students ${ }^{20}$.

At the beginning of the XXI century, the competition between exporting countries of education services has significantly increased. For example, such countries as the United Kingdom, Japan, Australia and France have adopted programs that provide the same level as the United States in years ahead. Approximately 500 thousand foreign students study in the mentioned countries every year. And their total tuition is about $\$ 13$ billion.

In the XXI century, in the context of globalization, the educational market is opened within the concept of transnationalization of education. The concept opens up tremendous prospects in the provision of education services to most age groups, that is, to the economically active population. For this reason, information technology is used $^{21}$. The concept of transnationalization of education defines, above all, the range of such educational services that can be provided through a variety of education programs: online or remotely as well as the establishment of branch units. It is also provided for the integration of training programs, singing of partnership agreements between educational institutions located in different countries for the implementation of joint programs ${ }^{22}$.

${ }^{20}$ Бахманов А. Общества знания - светлое будущее всего человечества. Реферат доклада ЮНЕСКО «К обществам знания». URL: http://subscribe.ru/archive/ (дата звернення 20.05.2019)

21 Доклад о развитии человека 2016. Опубликовано для Программы развития OОН (ПРООН). М.: Весь мир, 2016.Доклад о развитии человека 2016. URL: www.vesmirbooks.ru (дата звернення 22.05.2019)

${ }^{22}$ Глен Р.Дж. Как перебросить мост от сложных проблем транснационального образования к аккредитации. Высшее образование в Европе. 2015. T. XXVI. № 1. 
In the current conditions of globalization of the education system, assessment of the capacity of the global education services is quantitatively presented in UNESCO Report "To the knowledge society". Between 1970 and 1990, the number of university students increased from 28 million to 69 million, more than double, all over the world. As of 2002, there were 122 million students worldwide. According to the latest data, in 2016 the number of students is 150 million $^{23}$.

The main features and characteristics of the international education services market are the export of education services and education mobility.

The characteristics can be analysed and assessed relying on the data on international students' number studying in different countries. Study of international students in different countries is an important indicator of the integration level of the domestic education system into the world environment. As for education services export, today, there is its clear differentiation into 2 types: active export and passive export. Passive export has a long history and is related to student education in different countries of the world. Active export is characterized by foreign expansion of higher education institutions, that is, in other countries, branches of education institutions are created in terms of transnational corporations.

At the international level, China ranks first in the number of international students with specific gravity $67 \%$ of the overall number of students in the country. European countries are lower: Switzerland $18 \%$, Austria $-14 \%$, Belgium - 11\%, the United Kingdom, France, Germany $-10 \%$, Denmark $-9 \%$. And $18 \%$ and $10 \%$ of international students study in Australia and New Zealand.

Analyzing the structure of foreign students by home country, the paper concludes that in Africa, the largest share of students are African-born 73.0\%. In North America, higher education institutions were in demand by the population of the Americas $-33.6 \%$ and $23.4 \%$ respectively.

At the same time, higher education institutions in the United States of America are in high demand among European students - 62.5\%. And the vast majority of students in Canadian universities are students from Europe $-36 \%$ and $23.9 \%$ from Asia $^{24}$.

${ }^{23}$ Source 21.

24 Система образования в Дании - стране, практически всеобщей гармонии. URL: http://www. aboutstudy.ru/ (дата звернення 22.04.2019) 
Effective competition for resources of foreign students can take place under the purposeful state policy. Thus, since the last century, integral actors of the global market of education services have been specialized organisations which are functioning in many countries and deal with the attraction of foreign citizens to study in the country. They consist of national agencies; education funds; information centers and international exchange centers; different associations, councils, etc. ${ }^{25}$. Increased competition in different areas is an integral factor in globalization and characterizes the current development of the world education market.

Multiplication of universities in developing countries has become an important trend in recent decades. There is a significant increase in higher education institutions in the countries of Africa, Asia and Latin America. Despite the growing number of higher education institutions, it is still difficult for developing countries to compete with universities of developed countries. This situation happens primarily because higher education institutions of the countries mainly provide diploma programs rather than postgraduate education programs ${ }^{26}$.

The limited supply of postgraduate programs in developing countries explains another important trend in the development of the world education services market, that is, the distribution of foreign students through study programs in developed countries. Recently, the majority of fresh students have chosen MA and postgraduate training programs. Consequently, in the United States in 2016/17 academic year, 46.3\% of newly arrived foreign students applied for postgraduate programs (master's and postgraduate programs) and $40.5 \%$ chose to study under the major higher education programs (bachelor degree course) ${ }^{27}$.

Over the last 15 years, new leaders have emerged in the world market of education services. Australia made a serious step up. According to forecasts, the demand for Australian higher education will be 280848 people by 2025 .

The state regulation of the education services market is carried out for effective functioning, stimulation of the process of institutions'

${ }^{25}$ Айдрус И.А., Филиппов В.М. Мировой рынок образовательных услуг: Учеб. пособие. Москва: РУДН, 2017. 194 с.

${ }^{26}$ Глен Р.Дж. Как перебросить мост от сложных проблем транснационального образования к аккредитации. Высшее образование в Европе. 2015. T. XXVI. № 1.

${ }^{27}$ Source 24. 
establishment, ensuring national interests of producers and consumers of education services. Regulatory bodies include the ministry of education, services and agencies composing them. The ministries of education are entrusted with the functions of drafting and adopting legal acts, their implementation, realising public policy in the education sector as well as control over the activities of organizations composing their part ${ }^{28}$.

As the United States holds the leading position upon many indicators, it is expedient to consider the experience of the functioning of the education services market in the United States rather than anywhere else. The USA is characterized by a rather diversified structure stimulating the country's progress in the global education services market. The US Councils for International Education, the Association of International Educators, the Institute for International Education, the International Council for Research and Exchanges, and many other specialized organizations and foundations are engaged in promoting US education and attracting students from around the world. Thus, Education USA is a network of over 425 councils supported by the Bureau of Educational and Cultural Affairs and U.S. Department of State. The network promotes U.S. higher education abroad by offering accurate, current information about opportunities to study in the United States and guidance how best to gain access to the opportunities.

One of its internal activities is to inform U.S. universities on the importance of enrolling international students, on international education policy, on global education systems, and on how to maintain a welcoming atmosphere for international students ${ }^{29}$. Education funding is one of the most burning issues facing national governments and international organizations. The purpose of educational grants is to reduce student education expenditures. Grants are provided free of charge by the state, private companies, banks, charities etc. Different countries use various grant principles ${ }^{30}$.

Recently, education loan schemes have been promoting, in particular by finance office. There are similar schemes in almost 50 countries. In the USA, financial aid to students is rendered through such federal education loans as Stafford, PLUS, the Ford Direct Student Loan Program.

${ }^{28}$ Source 24.

${ }^{29}$ Source 25.

30 Айдрус И.А., Филиппов В.М. Мировой рынок образовательных услуг: Учеб. пособие. Москва: РУДН, 2017. 194 с. 
American students have the opportunity to receive financial aid for study abroad. Aid for international students is provided by some federal education programs such as Global UGRAD in Eurasia and Central Asia; the Edmund S. Muskie Fellowship Program (MUSKIE); the Hubert H. Humphrey Fellowship Program provides the opportunity to visit the USA to conduct research and enrich professionalism; Fulbright programs provide Graduate and Postgraduate Scholarships; "Opportunity Initiative", scholarships program supported by the U.S. Embassy, grants talented students who can receive financial assistance from U.S. universities covering a large portion of their tuition $\operatorname{costs}^{31}$.

\section{CONCLUSIONS}

In the context of globalization, the internationalization of economy gains new features: the global world production is formed based on intensification of activity of multinational corporations; the growth rate of international trade is ahead of the growth rate of production; the orientation and structure of international trade is changing, and exchange of science-based, high-tech products between developed countries is increasing; the orientation of developed economies on the activation of the human factor, the ability to generate new knowledge, to apply it quickly using modern methods of information processing is increasing; the search for a global center of management and tools for regulating global economic processes is intensifying.

The complex and contradictory processes of globalization, which have taken place in the world, are also reflected in the education sector. First of all, this concerns such issues as strategies for the development of international relations between higher education institutions; international education quality assurance, training of competitive experts; transnational education; information and communication technologies of education, establishment of virtual universities, introduction of non-traditional technologies of intensive learning; ensuring equality and access to higher education; the problem of migration of domestic intellectuals to the countries of industrial-information technologies.

It is necessary to find ways of convergence and gradual integration of different philosophical doctrines of education as the most important

31 Айдрус И.А., Филиппов В.М. Мировой рынок образовательных услуг: Учеб. пособие. Москва: РУДН, 2017. 194 с. 
condition for the formation of a unified world educational space, recognition of universal education and pedagogic ideal and values. These common challenges have clear interdisciplinary nature and are the subject of study of various sciences. The study of education as a sphere of formation of a man of the era is a topical and cognitive problem. The choice of the only right path is possible based on the consideration of people's interests and needs. The time of choice is today. It is impossible without comprehensive activation of the intellectual, spiritual potential of society, the growth of the general and political culture of the people. It is necessary for the vast majority of people living on the earth to develop general principles of life arrangements, to recover systematic and scientific nature to the foreign policy of the states. This is the ideological foundation of globalization.

\section{SUMMARY}

The paper studies key points of globalization as a socio-economic process. It analyses the positive and negative impact of the phenomenon on economic process. The author considers the interconnection of knowledge and progressive socio-economic development. The research covers the growing role of education, which is a condition for activation and increase of intellectual potential. It is noted that the only complex transformation and involvement of such powerful drivers of modern progress as science and the human factor can create something new that will make speed-up process stable and strong. The author analyses the mechanism of the functioning of modern markets of education services. It is presented recommendations on the promotion of competitiveness of future experts in the open market environment.

\section{REFERENCES}

1. Ямков В. Ранжування університетів крок до відкритості та прозорості вищої освіти. Освіта України. 2007. № 42.

2. Філіпенко А.С. Глобальні форми економічного розвитку: історія і сучасність. Київ: Знання, 2007. 670 с.

3. Мочерний С.В. Основи економічних знань. Київ: 1996. 405 с.

4. Гершунский Б.С. Философия образования для XXI века (В поисках практико-ориентированных образовательных концепций). М., 1997. 697 с. 
5. Менеджмент підприємницької діяльності: навч. посіб. для професійної підготовки військовослужбовців ЗС України, звільнених у запас. Вип. 6, Одеса: Видавничий дім «Гельветика». 2018. $240 \mathrm{c}$.

6. Смит А. Исследование о природе и причинах богатства народов. Москва: Соцэкгиз, 1956. 490 с.

7. Рикардо Д. Сочинения. М., 1995. Т. 1.365 с.

8. Иноземцев В. Л. К теории постэкономической общественной формации. Москва: Таурус, 1995. 302 с.

9. Хорос В. Постиндустриальный мир - надежды и опасения (к постановке проблемы).Москва: МЭ и МО. 1998. № 12.

10. Злупко С.М., Радецький Й.І. Людський потенціал, зайнятість i соціальний захист населення в Україні: Навчальний посібник. Львів: Видавничий центр ЛНУ імені Івана Франка, 2001. 192 с.

11. Brynjolfsson E., McAfee A., Spence M. New World Order. Labor, Capital, and Ideas in the Power Law Economy. Foreign Affairs. 2014. № 4, July - Aug. P. 19.

12. Игнатьев В.И. Социология информационного общества: учеб. посіб. Новосибирск: Изд-во НГТУ, 2017. 356 с.

13. Sigler M.G. Eric Schmidt: Every 2 Days We Create As Much Information As We Did Up To 2003. URL: http://techcrunch.com/ 2010/08/04/schmidt-data (дата звернення 25.05.2019)

14. Фейдл Ч., Бялик М., Триллинг Б. Четырёхмерное образование: компетенции, которые нужны для успеха. URL: http://nios.ru/sites/nios.ru/files/poleznoe/4D_Education_0.pdf (дата звернення 20.04.2019)

15. Гершунский Б.С. Философия образования для XXI века (В поисках практико-ориентированных образовательных концепций). Москва, 1997. 697 с.

16. Тоффлер Э. Шок будущего: Пер. с англ. М.: ООО «Издательство АСТ», 2002. 557 с.

17. Образование: сокрытое сокровище (Learning: The Treasure Within). Основные положения Доклада Международной комиссии по образованию для XXI века. МОО ВПП ЮНЕСКО «Информация для всех», 2007 г. URL:Www.unesco.org. (дата звернення 12.04.2019)

18. Аристотель. Сочинения в четырех томах. Т. 1. Ред. В. Ф. Асмус. Москва: Мысль, 1976. 550 с. 
19. Иванов Д.В. Путь к вершине. Факторы успеха. Управление развитием персонала. 2010. URL: https://grebennikon.ru/author3753.html (дата звернення 20.04.2019)

20. Бахманов А. Общества знания - светлое будущее всего человечества. Реферат доклада ЮНЕСКО «К обществам знания». URL: http://subscribe.ru/archive/ (дата звернення 20.05.2019)

21. Доклад о развитии человека 2016. Опубликовано для Программы развития ООН (ПРООН). М.: Весь мир, 2016. Доклад о развитии человека 2016. URL: www.vesmirbooks.ru (дата звернення 22.05.2019)

22.Глен Р.Дж. Как перебросить мост от сложных проблем транснационального образования к аккредитации. Высшее образование в Европе. 2015. Т. XXVI. № 1.

23. Система образования в Дании - стране, практически всеобщей гармонии. URL: http://www.aboutstudy.ru/ (дата звернення 22.04.2019)

24. Айдрус И.А., Филиппов В.М. Мировой рынок образовательных услуг: Учеб. пособие. М.: РУДН, 2017. 194 с.

25. Глен Р.Дж. Как перебросить мост от сложных проблем транснационального образования к аккредитации. Высшее образование в Европе. 2015. Т. XXVI. № 1.

26. Айдрус И.А., Филиппов В.М. Мировой рынок образовательных услуг: Учеб. пособие. Москва: РУДН, 2017. 194 с.

\section{Information about the author: Poluiaktova O. V. $\mathrm{PhD}$ in Economics,}

Senior Lecturer at the Department of Political Sciences and Law, State Institution «South Ukrainian National Pedagogical University named after K. D. Ushynsky» 26, Staroportofrankovskaya str., Odesa, 65000, Ukraine 